\title{
Correlation of Early Subarachnoid Hemorrhage on Serum Endothelin and von Willebrand Factor with Clinical and Radiological Parameters
}

\author{
Erken Dönem Subaraknoid Kanamanın Serum Endotelin ve von \\ Willebrand Faktörü Üzerindeki Etkisinin Klinik ve Radyolojik \\ Parametrelerle Korelasyonu
}

\author{
(D) Serkan Kitiş1, (D) Meliha Gündağ Papaker1, (D) Eray Metin Güler2 \\ ${ }^{1}$ Bezmialem Vakıf University Faculty of Medicine, Department of Neurosurgery, İstanbul, Turkey \\ ${ }^{2}$ Bezmialem Vakıf University Faculty of Medicine, Department of Biochemistry, İstanbul, Turkey
}

\section{Abstract}

Objective: This study aimed to determine the changes in endothelin and von Willebrand factor (VWF) serum levels during early period aneurysmal subarachnoid hemorrhage ( $\mathrm{SAH}$ ) compared to healthy individuals and to analyze them according to clinical and radiological findings.

Method: This is a prospective study consisting of 36 cases that were referred to our hospital's emergency department between January 2018 and January 2019 for aneurysmal SAH. The control group had the same demographic features as our patients. The diagnosis of aneurysmal SAH was confirmed by computed tomography (CT), CT angiography, and digital angiography within the first 6 hours after admission. The patients' blood samples were collected within 6 hours after the occurrence of severe headache. Endothelin and VWF levels in the blood of the patient and control groups were measured by photometric methods. The results were correlated with the endothelin and VWF levels of healthy individuals and compared with the patients' Glasgow Coma scale (GCS) and Fisher scale (FS) scores.

Results: Of the 36 patients included in this study, 24 (66.7\%) were female and 12 were male (33.3\%). The average age was 52.13 \pm 14.40 (range: 19 to 80 ) years. At the time of admission, GCS, and FS scores were 11.3 and 3.1 on average, respectively. A total of 36 healthy individuals ( 24 females and 12 males) with an average age of $49.6 \pm 11.7$ (range: 22 to 76 ) years were included in the control group. A significant negative correlation was found between the FS score and the GCS score of the patients ( $r=-0.501$, $p=0.002$ ). There was a significant correlation between the GCS score of the patients and the endothelin and VWF values. It was observed that

\section{Öz}

\begin{abstract}
Amaç: Biz bu çalışmada, anevrizmal subaraknoid kanamanın (SAK) erken döneminde hastaların serum endotelin ve von Willebrand faktörü (vWF) düzeylerinin sağlıkı kişilere göre artışını belirlemeyi ve klinik ve radyolojik bulgulara göre analiz etmeyi amaçladık.
\end{abstract}

Yöntem: Çalışmamız, Ocak 2018 ile Ocak 2019 arasında anevrizmal SAK nedeniyle hastanemiz acil servisimize başvuran 36 olgunun oluşturduğu prospektif bir çalışmadır. Kontrol grubunu, hastalarımızla aynı demografik özellikleri taşıyan sağlıklı bireyler oluşturdu. Anevrizmal SAK tanısı, başvurudan sonraki ilk 6 saat içinde bilgisayarlı tomografi (BT), BT anjiyografi ve dijital anjiyografi ile doğrulandı. Hastaların kan numuneleri şiddetli baş ağrısının ortaya çıkmasından sonraki 6 saatlik sürede toplandı. Hastaların ve kontrol grubunun kanlarında endotelin ve vWF düzeyleri fotometrik yöntemlerle ölçüldü. Sonuçlar, sağlıklı kişilerin endotelin ve vWF düzeyleri ile ve hastaların Glasgow Koma skalası (GKS), Fisher skalası (FS) sonuçları ile karşılaştırılarak korele edildi.

Bulgular: Çalışmamıza dahil edilen 36 hastanın 24'ü $(\% 66,7)$ kadın ve 12 'si erkek $(\% 33,3)$ idi. Ortalama yaş 52,13 $\pm 14,40$ (dağılım: 19-80) yıldı. Hastaların başvuruları sırasında GKS ve FS sırasıyla ortalama 11,3 ve 3,1 idi. Kontrol grubuna yaş ortalaması 49,6 $\pm 11,7$ (dağılım: 22-76) olan 36 (24 kadın ve 12 erkek) sağlıkı birey dahil edildi. Hastaların FS skorları ve GKS skorları arasında anlamlı negatif korelasyon bulundu $(r=-0,501, p=0,002)$. Hastaların GKS skorları ile endotelin ve vWF değerleri arasında anlamlı bir korelasyon saptandı. GKS skoru düştükçe artan oranda bir endotelin ve vWF değerleri olduğu görüldü $(r=-0,465 p=0,004, r=-0,465 p=0,004)$. Hastaların FS skorları ile endotelin ve vWf değerleri arasında da anlamlı

Address for Correspondence: Serkan Kitiş, Bezmialem Vakıf University Faculty of Medicine, Department of Neurosurgery, İstanbul, Turkey E-mail: serkankitis@yahoo.com ORCID: orcid.org/0000-0002-9119-5899 Received: 15.06.2020 Accepted: 28.07.2020

Cite this article as: Kitiş S, Gündağ Papaker M, Güler EM. Correlation of Early Subarachnoid Hemorrhage on Serum Endothelin and von Willebrand Factor with Clinical and Radiological Parameters. Bagcilar Med Bull 2020;5(3):100-106

${ }^{\circ}$ Copyright 2020 by the Health Sciences University Turkey, Bagcilar Training and Research Hospital Bagcilar Medical Bulletin published by Galenos Publishing House. 


\section{Abstract}

there was an increasing rate of endothelin and vWF values as the GCS score decreased $(r=-0.465 p=0.004, r=-0.465 p=0.004)$. There was also a significant relationship between FS score and endothelin and VWF values. It was observed that as FS score increased, endothelin, and VWF values also increased $(r=0.571, p<0.001, r=0.538, p=0.001)$.

Conclusion: Evidence suggests that inflammation plays an important role in the acute phases of aneurysmal SAH-related neural damage. Our study showed that serum endothelin and VWF levels increased in the first day of bleeding in aneurysmal SAH patients and that they were associated with the GCS and FS scores.

Keywords: Endothelin, Fisher scale, subarachnoid hemorrhage, von Willebrand factor

\section{Öz}

bir ilişki kaydedildi. FS skoru arttıkça artan bir endotelin ve vWF değerleri olduğu görüldü $(r=0,571, p<0,001, r=0,538, p=0,001)$.

Sonuç: Ortaya çıkan kanıtlar, anevrizmal SAK ile ilişkili nöral hasarın akut fazlarında enflamasyonun önemli bir rol oynadığını göstermektedir. Çalışmamız anevrizmal SAK hastalarında kanamanın ilk gününde serum endotelin ve vWF düzeylerinin arttığını ve bunların GKS ve FS skorlarıyla ilişkili olduğunu göstermiştir.

Anahtar kelimeler: Endotelin, Fisher skalası, subaraknoid kanama, von Willebrand faktör

\section{Introduction}

Subarachnoid hemorrhage (SAH), which means bleeding in the subarachnoid space, is a critical situation associated with high morbidity and mortality. Typically, the first and only symptom of SAH is sudden and serious headache, which is defined as the most severe headache in life. Although the most common cause of SAH in the literature is trauma, the most common cause of non-traumatic SAH is aneurysm ruptures (80-85\%). With regard to the remaining causes, it is seen that approximately $10 \%$ of them are nonaneurysmal perimesencephalic SAH and among the rest, the leading ones are due to vascular malformation or vasculitis (1-3).

Factors significantly associated with unfavorable outcomes after SAH include the neurological status on the day of admission and the amount of blood in computed tomography (CT) on admission. The Glasgow Coma scale (GCS) is frequently used for evaluating patients with neurological conditions. In the radiological grading of $\mathrm{SAH}$, the Fisher scale (FS) which is based on CT, is used as a Reliable scale to determine SAH severity (4).

When blood is present in the subarachnoid space, the components in the blood content act as powerful activators of neuroinflammation. This neuroinflammation plays an important role in the initial injury that occurs at the first moment of the SAH and in subsequent secondary injuries. Many factors contribute to the activation of neuroinflammation after $\mathrm{SAH}(5,6)$. In addition, some studies have found that vasoactive and spasmogenic compounds can be described in high concentrations in the cerebrospinal fluid (CSF) and plasma of patients with SAH $(7,8)$.

Endothelin is a potent vasoconstrictor peptide from the endothelium, which is released after endothelial cell injury. According to the literature, it has been related to the mechanism of cerebral vasospasm (CVS) that develops after aneurysmal hemorrhage (9-12). Similarly, experimental and clinical studies have pointed von Willebrand factor (vWF), which increases in circulation, as a marker of vascular damage. Plasma vWF is synthesized and secreted mainly from vascular endothelial cells. When endothelial cells are activated or injured, their expression increases and may indicate endothelial dysfunction and/or susceptibility to thrombosis (13).

We aimed to determine the change in endothelin and vWF serum levels in early period aneurysmal SAH compared to healthy individuals and to analyze them according to clinical and radiological findings.

\section{Materials and Methods}

\section{Patient Population, Data Collection, and Control Participants}

Our prospective study consisted of cases that were referred to our hospital's emergency department for non-traumatic SAH between January 2018 and January 2019. Our institution's ethics committee approved this prospective study (decision number: 2018.20/264). The data used in this study were collected prospectively without any risk for patients. A total of 36 patients who were referred to our emergency unit due to non-traumatic SAH were included in this study.

The control participants, consisting of healthy individuals who presented to our outpatient clinic with headache in the same period but did not have any cranial pathology based on brain magnetic resonance imaging findings, were included in this study. The control group had the same demographic features as the patient group. The 
control group patients were informed about the study and informed consent was obtained.

Clinical and neurological status evaluation of the patients was made according to the GCS score. The GCS score was evaluated as 3-8 for severe, 9-13 for moderate, and 14-15 for mild neurological damage. In the radiological grading of SAH, FS was performed to determine the SAH severity (Table 1).

\section{Inclusion Criteria}

Thirty-six patients referred to the emergency department due to severe headache, altered consciousness, and the development of neurology deficit were included. All of these patients were radiologically and clinically diagnosed within the first 6 hours of admission. Patients who had SAH due to trauma (even if there was an underlying aneurysmatic/ vascular pathology) were not included in this study. Patients with negative aneurysms in digital angiography (DSA) were excluded from the study.

Patients who were admitted after trauma or were known to have coagulation abnormalities, active/chronic infection, malignancy, kidney or liver dysfunction, severe myocardial dysfunction and/or any other immune deficiency syndrome (such as AIDS, lymphoma, leukemia) were excluded from the study.

The diagnosis of aneurysmal SAH was confirmed by CT, CT angiography, and DSA within the first 6 hours after admission. All the patients with aneurysm were included in either surgical or endovascular treatment within the first 24 hours.

\section{Blood Sample Collection}

Since the patients' serum endothelin and vWF levels changed over time, the patients' blood samples were collected within 6 hours after the occurrence of the severe headache. Blood samples collected from the cubital vein in the volunteer patients and healthy individuals were put into the gel biochemistry tubes and centrifuged at $3.500 \mathrm{~g}$ for 10 minutes at room temperature after coagulation. The separated serums were stored at $-80^{\circ} \mathrm{C}$ until the study was completed.

\section{Table 1. Fisher scale}

\section{CT finding}

1 No SAH

2 Diffuse thin $(<1 \mathrm{~mm}) \mathrm{SAH}$

3 Localized clots and/or layers of blood $>1 \mathrm{~mm}$ in thickness

4 Diffuse or no $\mathrm{SAH}$, intraventricular or parenchymal blood present

SAH: Subarachnoid hemorrhage, CT: Computed tomography

\section{Measurement of Endothelin and vWF Levels}

Serum endothelin (Bioassay technology laboratory, Shangai-China - E1238Hu) and vWF (Bioassay technology laboratory, Shangai-China - E1774Hu) levels were measured at $450 \mathrm{~nm}$ with photometric methods using commercially purchased kits. Results were reported as ng/L for endothelin and $\mathrm{ng} / \mathrm{mL}$ for $\mathrm{vWF}$.

\section{Statistical Analysis}

Data analysis was done using Statistical Package for the Social Sciences (SPSS) 21.0 statistics program. In addition to descriptive statistics, frequency, percent value, mean and standard deviation were used to identify the demographic characteristics of the cases. Data with normal distribution were evaluated by the independent sample t-test. The p-value $<0.05$ was considered significant. The normality of the distribution was evaluated by the Kolmogorov-Smirnov test. For correlation analysis, the Spearman correlation test was used. Statistical significance was accepted when p-values were $<0.05$.

\section{Results}

Of the 36 patients included in our study, 24 (66.7\%) were female and $12(33.3 \%)$ were male. The average age was $52.13 \pm 14.40$ (range: 19 to 80 ) years. At the time of admission, GCS and FS were 11.3 and 3.1 on average, respectively. A total of 36 healthy individuals ( 24 females and 12 males) with an average age of $49.6 \pm 11.7$ (range: 22 to 76 ) years were also included in the control group. The difference was statistically insignificant ( $>0.05$ ). The age, gender, location of ruptured aneurysm, FS, and GCS scores of each patient were recorded (Table 2).

There was a significant difference in endothelin and $\mathrm{vWB}$ values between patients and control participants $(p<0.001)$. A statistically significant difference was observed in the increasing trend after bleeding (Table 3).

A significant negative correlation was found between the FS and GCS scores of the patients $(\mathrm{r}=-0.501, \mathrm{p}=0.002)$. There was a significant correlation between the GCS score of the patients and the endothelin and vWF values. It was observed that there was an increasing rate of endothelin and $\mathrm{vWF}$ values as the GCS score decreased $(\mathrm{r}=-0.465$ $\mathrm{p}=0.004 ; \mathrm{r}=-0.465 \mathrm{p}=0.004$ ). There was also a significant relationship between FS and endothelin and vWF values. It was observed that as FS increased, endothelin and vWF values also increased $(r=0.571, p<0.001 ; r=0.538, p=0.001)$ (Table 4). 


\begin{tabular}{ll}
$\begin{array}{l}\text { Table 2. Baseline demographic and clinical characteristics } \\
\text { of patients }\end{array}$ & $\mathbf{n}=\mathbf{3 6}$ \\
\hline Gender & \\
Female & $24(66.7 \%)$ \\
Male & $12(33.3 \%)$ \\
Age & 52.13 \\
Location of aneurysm & \\
Anterior circulation & $32(88.9 \%)$ \\
Posterior circulation & $4(11.1 \%)$ \\
Treatment & \\
Surgical treatment & $18(50 \%)$ \\
Endovascular treatment & $18(50 \%)$ \\
Glasgow Coma scale & Mean 11.3 \\
(3-8) & 10 \\
(9-13) & 7 \\
(14-15) & 19 \\
Fisher scale & 13 \\
1 & Mean 3.1 \\
2 & 0 \\
3 & 8 \\
\hline N: Total number of patients & 15 \\
&
\end{tabular}

\section{Discussion}

This study shows that circulating endothelin and vWF increased significantly in patients with SAH. It also shows that serum endothelin and vWF levels increase as the patients' initial admission GCS score worsens and they tend to increase in parallel with an increase in the amount of blood on tomography.

Subarachnoid hemorrhage causes early brain damage due to temporary cerebral ischemia and the toxic effects of subarachnoid blood. It also causes secondary brain damage due to increased intracranial pressure, destruction with intracerebral hemorrhage, formed shifting, and herniation $(14,15)$. Also, there is a delayed brain injury stage due to cerebral ischemia caused by CVS between the $3^{\text {rd }}$ and $14^{\text {th }}$ days of hemorrhage (16). SAH also generates a systemic response that can cause a Systemic Inflammatory Response syndrome. Increased plasma inflammatory cytokines contribute to this systemic response (17-22).

When endothelial cells are stimulated by cytokines or vascular damage, the barrier function of the endothelium is impaired. Vasomotion is impaired due to an increase or decrease in the production of vasoactive substances,

\begin{tabular}{|c|c|c|c|c|c|}
\hline & Mean & $\mathbf{n}$ & SD & $\mathbf{t}$ & p \\
\hline Endothelin-SAH & 66.4583 & 36 & 46.80790 & 6.690 & $<0.001$ \\
\hline Endothelin-control & 14.8589 & 36 & 5.22645 & - & - \\
\hline vWF-SAH & 40.7885 & 36 & 18.08301 & 10.812 & $<0.001$ \\
\hline vWF-control & 8.9959 & 36 & 3.30477 & - & - \\
\hline
\end{tabular}

SAH: Subarachnoid hemorrhage, vWF: von Willebrand factor, SD: Standard deviation, N: Total number of patients, t: Statistical t parameter

\begin{tabular}{|c|c|c|c|c|c|}
\hline & & GCS & FS & Endothelin & vWF \\
\hline \multirow{3}{*}{ GCS } & Correlation coefficient & 1.000 & $-0.50 * *$ & $-0.465^{* *}$ & $-0.465^{* *}$ \\
\hline & Sig. (2-tailed) & 0 & 0.002 & 0.004 & 0.004 \\
\hline & $\mathrm{n}$ & 36 & 36 & 36 & 36 \\
\hline \multirow{3}{*}{ FS } & Correlation coefficient & $-0.501^{* *}$ & 1.000 & $0.571^{* *}$ & $0.538^{* *}$ \\
\hline & Sig. (2-tailed) & 0.002 & 0 & 0.000 & 0.001 \\
\hline & $\mathrm{n}$ & 36 & 36 & 36 & 36 \\
\hline \multirow{3}{*}{ Endothelin } & Correlation coefficient & $-0.465^{* *}$ & $0.571^{* *}$ & 1.000 & $0.693^{* *}$ \\
\hline & Sig. (2-tailed) & 0.004 & 0.000 & 0 & 0.000 \\
\hline & $\mathrm{n}$ & 36 & 36 & 36 & 36 \\
\hline \multirow{3}{*}{ vWF } & Correlation coefficient & $-0.465^{* *}$ & $0.538^{* *}$ & $0.693^{* *}$ & 1.000 \\
\hline & Sig. (2-tailed) & 0.004 & 0.001 & 0.000 & 0 \\
\hline & $\mathrm{n}$ & 36 & 36 & 36 & 36 \\
\hline
\end{tabular}

vWF: von Willebrand factor, FS: Fisher scale, GCS: Glasgow Coma scale, **: It is a statistical sign showing that it is statistically very strongly related, N: Total number of patients 
and prothrombotic/procoagulant activity increases. Vasoconstriction, leukocyte adhesion, platelet activation, affinity to thrombosis, coagulation disorders, pro-oxidative changes, and vascular inflammation occur $(23,24)$.

While the NO, prostacyclin, and endothelium-induced hyperpolarizing factor released from the endothelium have vasodilation activities in the arrangement of the endothelial vascular tonicity, endothelin has a vasoconstrictor activity. Structurally, endothelin has three forms. Endothelin-1 (ET1) is synthesized in endothelial cells, ET-2 in intestinal cells, and ET-3 in neurons. There are two types of endothelin receptors (ET-A and ET-B) in the vessel wall. ET-1, which is mainly responsible for vasoconstriction, is not stored in endothelial cells, but de novo synthesized with stimuli such as thrombin, angiotensin II, shear stress, and hypoxia (2528). In the SAH model performed by Lei et al. (29) on rabbits, they showed that ET- 1 affected cerebral microcirculation after SAH by perfusion CT scan. They found that ET-1 increased in CSF and peripheral blood after SAH, and showed that blood circulation perfusion decreased when ET-1 increased (29). The clinical study conducted by Zimmermann and Seifert (30) supports the hypothesis that ET-1 is the main cause of CVS after SAH.

Another plasma protein that occurs in endothelial injured is vWF, which is a plasma glycoprotein that is a mediator of platelet adhesion. vWF is constantly secreted into the plasma by the endothelium and is also stored in the Weibel-Palade bodies in endothelial cells. When endothelial cells are stimulated, membrane fusion of the bodies causes large amounts of vWF to pass into the blood and mechanisms that result in platelet aggregation/ thrombus formation begin (31-34). In the study of McGirt et al. (32) based on the previous studies about morphological changes caused by endothelial cell damage in peripheral vasculature, they showed increases in serum vWF, MMP-9, and VEGF levels before the development of CVS and predicted the onset of CVS correctly. Tang et al. (33) have assumed that the vWF/ADAMTS13 balance plays an important role in thrombosis; they have shown that a decrease in ADAMTS13 activity causes less disruption of vWF and thus an increase in vWF activity. They have assumed that endothelial dysfunction and unbalanced vWF/ADAMTS13 are correlated with delayed cerebral ischemia formation and poor clinical outcome (33). Similarly, Wan et al. (31) showed that vWF/ADAMTS13 was associated with pathogenesis in early brain injury, and that ultra-early treatment with rADAMTS-13 reduced early brain damage after experimental SAH.
In our study, we found a significant difference in the early serum endothelin and vWF values of patients who had SAH compared to the control group participants. In the early days of bleeding, we observed that both serum endothelin and vWF levels were higher in patients than in normal subjects.

Also, we compared the FS scores of the patients with their serum endothelin and vWF levels. FS used to evaluate neurological prognosis in $\mathrm{SAH}$ is the first and the best known classification system for SAH in CT scans. This scale is useful in predicting mortality, morbidity and/or CVS. FS evaluates the amount of blood seen on CT and predicts the prognosis of the clinical result. Clinical studies on the factors responsible for neuroinflammation have shown that SAH patients with high FS have significantly higher inflammatory factor levels in both plasma and CSF compared to SAH patients with low FS (35-37).

We found that in accordance with current literature, there is a significant correlation between serum endothelin and vWF levels and the FS. It was observed that as FS increased, endothelin and vWF values increased and they tended to increase in parallel with the increase in the amount of blood on tomography.

The limitation of our study is that we had a small sample size and only a single time point (early stage) was observed.

\section{Conclusion}

Evidence suggests that inflammation plays an important role in the acute phases of aneurysmal SAH-related neural damage. Our study showed that serum endothelin and vWF levels increased in the first day of bleeding in aneurysmal SAH patients and that they were associated with GCS and FS scores. The endothelium dysfunction and platelet activation were correlated with the occurrence of clinical outcomes. This is a preliminary clinical study that can be used as a basis in future studies.

\section{Ethics}

Ethics Committee Approval: The non-interventional ethics committee of Bezmialem Vakıf University has approved this prospective study (decision number: 2018.20/264).

Informed Consent: Informed consent was obtained.

Peer-review: Externally peer-reviewed

\section{Authorship Contributions}

Concept: S.K., M.G.P., Design: S.K., M.G.P., Data Collection or Processing: S.K., M.G.P., E.M.G., Analysis or Interpretation: 
S.K., M.G.P., E.M.G., Literature Search: S.K., M.G.P., Writing: S.K., M.G.P.

Conflict of Interest: The authors declare that they have no conflict of interest.

Financial Disclosure: The authors declared that this study has received no financial support.

\section{References}

1. van Gijn J, Kerr RS, Rinkel GJ. Subarachnoid haemorrhage. Lancet 2007;369(9558):306-318.

2. Steiner T, Juvela S, Unterberg A, Jung C, Forsting M, Rinkel G, et al. European stroke organization guidelines for the management of intracranial aneurysms and subarachnoid haemorrhage. Cerebrovasc Dis 2013;35(2):93-112.

3. Eren B, Karagoz Guzey F, Yucel M, Aktas OY, Tas A, Tufan A, et al. microsurgical clipping of anterior circle of willis aneurysms: a retrospective study. Bagcilar Medical Bulletin 2017;2(1):19-24.

4. Dündar TT, Kitiş S, Abdallah A, Yurtsever İ, Gülen G. Evaluation of the platelet volume index as a prognostic factor after aneurysmal subarachnoid hemorrhage. J Surg Med 2019;3(9):685-688.

5. Caffes N, Kurland DB, Gerzanich V, Simard JM. Glibenclamide for the treatment of ischemic and hemorrhagic stroke. Int J Mol Sci 2015;16(3):4973-4984.

6. Makino H, Tada Y, Wada K, Liang EI, Chang M, Mobashery S, et al. Pharmacological stabilization of intracranial aneurysms in mice: a feasibility study. Stroke 2012;43(9):2450-2456.

7. Fujiwara S, Kassell NF, Sasaki T, Nakagomi T, Lehman RM. Selective hemoglobin inhibition of endothelium-dependent vasodilation of rabbit basilar artery. J Neurosurg 1986;64(3):445-452.

8. Seifert V, Stolke D, Kaever V, Dietz H. Arachidonic acid metabolism following aneurysm rupture. Evaluation of cerebrospinal fluid and serum concentration of 6-keto-prostaglandin F1 alpha and thromboxane B2 in patients with subarachnoid hemorrhage. Surg Neurol 1987;27(3):243-252.

9. Xie A, Aihara Y, Bouryi VA, Nikitina E, Jahromi BS, Zhang ZD, et al. Novel mechanism of endothelin-1-induced vasospasm after subarachnoid hemorrhage. J Cereb Blood Flow Metab 2007;27(10):1692-1701.

10. Zubkov AY, Rollins KS, Parent AD, Zhang J, Bryan RM Jr. Mechanism of endothelin-1-induced contraction in rabbit basilar artery. Stroke 2000;31(2):526-533.

11. Hino A, Tokuyama Y, Kobayashi M, Yano M, Weir B, Takeda J, et al. Increased expression of endothelin B receptor mRNA following subarachnoid hemorrhage in monkeys. J Cereb Blood Flow Metab 1996;16(4):688-697.

12. Itoh S, Sasaki T, Asai A, Kuchino Y. Prevention of delayed vasospasm by an endothelin ETA receptor antagonist, BQ-123: change of ETA receptor mRNA expression in a canine subarachnoid hemorrhage model. J Neurosurg 1994;81(5):759-764.

13. Ruggeri ZM, Ware J. The structure and function of von Willebrand factor. Thromb Haemost 1992;67(6):594-599.

14. Fujii M, Yan J, Rolland WB, Soejima Y, Caner B, Zhang JH. Early brain injury, an evolving frontier in subarachnoid hemorrhage research. Transl Stroke Res 2013;4(4):432-446.
15. Matz PG, Fujimura M, Lewen A, Morita-Fujimura Y, Chan PH. Increased cytochrome c-mediated DNA fragmentation and cell death in manganese-superoxide dismutase-deficient mice after exposure to subarachnoid hemolysate. Stroke 2001;32(2):506-515.

16. Macdonald RL, Schweizer TA. Spontaneous subarachnoid haemorrhage. Lancet 2017;389(10069):655-666.

17. Hinson HE, Sheth KN. Manifestations of the hyperadrenergic state after acute brain injury. Curr Opin Crit Care 2012;18(2):139145 .

18. Tam AK, Ilodigwe D, Mocco J, Mayer S, Kasel N, Ruefenacht D, et al. Impact of systemic inflammatory response syndrome on vasospasm, cerebral infarction, and outcome after subarachnoid hemorrhage: exploratory analysis of CONSCIOUS-1 database. Neurocrit Care 2010;13(2):182-189.

19. Gao C, Liu X, Shi H, Xu S, Ji Z, Wang C, et al. Relationship between sympathetic nervous activity and inflammatory response after subarachnoid hemorrhage in a perforating canine model. Auton Neurosci 2009;147(1-2):70-74.

20. Chen S, Li Q, Wu H, Krafft PR, Wang Z, Zhang JH. The harmful effects of subarachnoid hemorrhage on extracerebral organs. Biomed Res Int 2014;2014:858496.

21. Fisher CM, Kistler JP, Davis JM. Relation of cerebral vasospasm to subarachnoid hemorrhage visualized by computerized tomographic scanning. Neurosurgery 1980;6(1):1-9.

22. Hijdra A, van Gijn J, Nagelkerke NJ, Vermeulen M, van Crevel H. Prediction of delayed cerebral ischemia, rebleeding, and outcome after aneurysmal subarachnoid hemorrhage. Stroke 1988;19(10):1250-1256.

23. Landmesser U, Drexler H. The clinical significance of endothelial dysfunction. Curr Opin Cardiol 2005;20(6):547-551.

24. Grover-Páez F, Zavalza-Gómez AB. Endothelial dysfunction and cardiovascular risk factors. Diabetes Res Clin Pract 2009;84(1):110.

25. Barton M, Yanagisawa M. Endothelin: 20 years from discovery to therapy. Can J Physiol Pharmacol 2008;86(8):485-498.

26. Rubanyi GM, Botelho LH. Endothelins. FASEB J 1991;5(12):27132720 .

27. Mayberg MR, Okada T, Bark DH. Morphologic changes in cerebral arteries after subarachnoid hemorrhage. Neurosurg Clin N Am 1990;1(2):417-432.

28. Kapp JP, Neill WR, Neill CL, Hodges LR, Smith RR: The three phases of vasospasm. Surg Neurol 1982;18(1):40-45.

29. Lei Q, Li S, Zheng R, Xu K, Li S. Endothelin-1 expression and alterations of cerebral microcirculation after experimental subarachnoid hemorrhage. Neuroradiology 2015;57(1):63-70.

30. Zimmermann M, Seifert V. Endothelin and subarachnoid hemorrhage: an overview. Neurosurgery 1998;43(4):863-876.

31. Wan H, Wang Y, Ai J, Brathwaite S, Ni H, Macdonald RL, et al. Role of von Willebrand factor and ADAMTS-13 in early brain injury after experimental subarachnoid hemorrhage. J Thromb Haemost 2018;16(7):1413-1422.

32. McGirtMJ,LynchJR, BlessingR, Warner DS, FriedmanAH, Laskowitz DT. Serum von Willebrand factor, matrix metalloproteinase-9, and vascular endothelial growth factor levels predict the onset of cerebral vasospasm after aneurysmal subarachnoid hemorrhage. Neurosurgery 2002;51(5):1128-1135. 
33. Tang QF, Lu SQ, Zhao YM, Qian JX. The changes of von willebrand factor/a disintegrin-like and metalloprotease with thrombospondin type I repeats-13 balance in aneurysmal subarachnoid hemorrhage. Int J Clin Exp Med 2015;8(1):13421348 .

34. Kumar M, Cao W, McDaniel JK, Pham HP, Raju D, Nawalinski K, et al. Plasma ADAMTS13 activity and von Willebrand factor antigen and activity in patients with subarachnoid haemorrhage. Thromb Haemost 2017;117(4):691-699.

35. Cheng YW, Li WJ, Dou XJ, Jia R, Yang H, Liu XG, et al. Role of endothelin-1 and its receptors in cerebral vasospasm following subarachnoid hemorrhage. Mol Med Rep 2018;18(6):5229-5236.
36. Al-Mufti F, Amuluru K, Damodara N, Dodson V, Roh D, Agarwal $\mathrm{S}$, et al. Admission neutrophil-lymphocyte ratio predicts delayed cerebral ischemia following aneurysmal subarachnoid hemorrhage. J Neurointerv Surg 2019;11(11):1135-1140.

37. Suzuki R, Masaoka H, Hirata Y, Marumo F, Isotani E, Hirakawa K. The role of endothelin-1 in the origin of cerebral vasospasm in patients with aneurysmal subarachnoid hemorrhage. J Neurosurg 1992;77(1):96-100. 